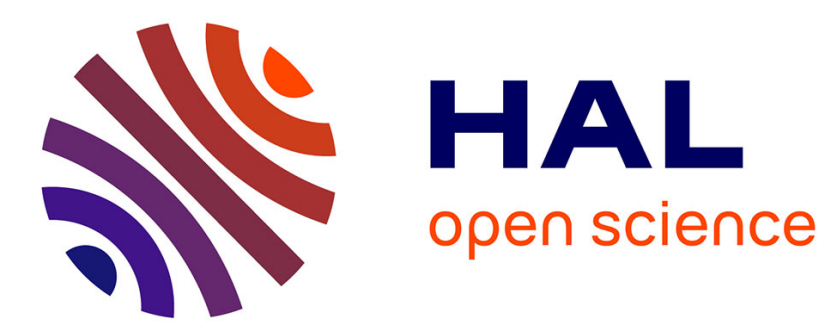

\title{
Electrochemical study of reactions at interfaces of glucose oxidase collagen membranes
}

\author{
Pierre R. Coulet, Robert Sternberg, Daniel R. Thevenot
}

\section{To cite this version:}

Pierre R. Coulet, Robert Sternberg, Daniel R. Thevenot. Electrochemical study of reactions at interfaces of glucose oxidase collagen membranes. Biochimica et Biophysica Acta (BBA) - Enzymology, 1980, 612, pp.317-327. 10.1016/0005-2744(80)90114-X . hal-01179303

\section{HAL Id: hal-01179303 \\ https://hal.science/hal-01179303}

Submitted on 23 Jul 2015

HAL is a multi-disciplinary open access archive for the deposit and dissemination of scientific research documents, whether they are published or not. The documents may come from teaching and research institutions in France or abroad, or from public or private research centers.
L'archive ouverte pluridisciplinaire HAL, est destinée au dépôt et à la diffusion de documents scientifiques de niveau recherche, publiés ou non, émanant des établissements d'enseignement et de recherche français ou étrangers, des laboratoires publics ou privés. 
Biochimica et Biophysica Acta, 612 (1980) 317-327

(C) Elsevier/North-Holland Biomedical Press

BBA 68964

\title{
ELECTROCHEMICAL STUDY OF REACTIONS AT INTERFACES OF GLUCOSE OXIDASE COLLAGEN MEMBRANES
}

\author{
PIERRE R. COULET ${ }^{a}$, ROBERT STERNBERG ${ }^{b}$ and DANIEL R. THÉVENOT ${ }^{b}$ \\ ${ }^{a}$ Laboratoire de Biologie et Technologie des Membranes du CNRS, Université Claude \\ Bernard, LYON I, 43 Boulevard du 11 Novembre 1918, F-69621 Villeurbanne, and \\ ${ }^{\mathrm{b}}$ Equipe de Bioélectrochimie et d'Analyse du Milieu, Laboratoire d'Energétique \\ Biochimique, Université Paris Val de Marne, Avenue du Général de Gaulle, F-94010 Créteil \\ Cedex (France)
}

(Received July 31st, 1979)

Key words: Electrochemistry; Interface; Glucose oxidase; Collagen membrane

\section{Summary}

The operational behaviour of enzyme collagen membranes with surface-bound glucose oxidase has been studied by simultaneously recording the current outputs of two platinum anodes: whereas the first one was close to the enzymatic membrane, the second was placed into the bulk solution. Steady-state responses of both electrodes were measured when either glucose or hydrogen peroxide were added to the stirred buffer solution. They were used to determine the hydrogen peroxide fluxes, $v_{1}$ (towards the first electrode) and $v_{2}$ (towards the bulk phase). The glucose concentration and temperature dependence of $v_{1}$ and $v_{2}$ have been studied and the importance of diffusional limitations on the overall reaction rates were determined. Comparison of freely stirred and mounted enzymatic membrane enabled us to determine an equivalent working area at high glucose concentration.

\section{Introduction}

Collagen membranes having undergone an acyl-azide activation process are specially suitable for enzyme coupling [1] and the enzymic membranes obtained can be used either in enzymatic catalysis studies [2,3] or in analytical devices [4]. As shown with a large variety of enzyme-support conjugates, diffusional limitations appear to be one of the main results of immobilization

Abbreviations: ABTS, 2,2'-azino-di-(3-ethyl-benzthiazoline)sulfonate; $\mathrm{E}_{1}$, electrode close to membrane; $\mathrm{E}_{2}$, electrode in bulk solution. 
[5,6]. Previously reported data obtained with collagen-bound aspartate aminotransferase have shown that kinetics can be modified after coupling: the enzyme exhibits a greater affinity for glutamate but a lower affinity for oxaloacetate [2] and the modified behaviour could be explained by differential diffusion limitations for the two substrates [7]. In this case, the measurements were performed with enzymic membranes freely immersed in the reaction vessel under constant stirring. With a more sophisticated approach, using a rotating membrane reactor and sorbitol dehydrogenase [8] the direct visualization of diffusional effects on the enzyme behaviour could be obtained. This paper presents a more complex situation where a glucose oxidase collagen membrane is pressed on a platinum anode. In our case, enzyme molecules are not randomly distributed inside the membrane but form two distinct layers [9]. One of these layers is in close contact with the platinum anode whereas the other is exposed to the stirred substrate solution. Hydrogen peroxide, one of the reaction products of the reduction of oxygen with glucose in the presence of glucose oxidase can be amperometrically detected in the immediate vicinity of the inner enzyme layer, thus providing a measurement of the membrane activity under these conditions. On the other hand, hydrogen peroxide diffusing towards the bulk solution can also be monitored amperometrically with another sensor, thus providing a second measurement of the membrane activity. This paper presents the relation between these two simultaneous monitorings of the same enzyme activity and their dependence on glucose concentration and temperature, taking into account diffusional effects.

\section{Materials and Methods}

\section{Solutions and reagents}

Insoluble films of highly polymerized reconstituted collagen, F70 type, were a gift of the Centre Technique du Cuir, Lyon, France. They are $20 \mathrm{~cm}$ wide and their thickness is about $0.1 \mathrm{~mm}$ in a dry state and $0.3-0.5 \mathrm{~mm}$ when swollen. Lyophilized $\beta$-D-glucose oxidase of fungal origin ( $\beta$-D-glucose:oxygen 1 -oxidoreductase, EC 1.1.3.4, grade I, $210 \mathrm{U} / \mathrm{mg}$ ), peroxidase from horseradish (donor:hydrogen-peroxide oxidoreductase, EC 1.11.1.7, grade I, $250 \mathrm{U} / \mathrm{mg}$ ), bovine liver catalase (hydrogen-peroxide:hydrogen-peroxide oxidoreductase, EC 1.11.1.6, $65000 \mathrm{U} / \mathrm{mg}$ ) and 2,2'-azino-di-(3-ethyl-benzthiazoline)sulfonate (ABTS) were supplied by Boehringer Mannheim.

The stock solution of $0.1 \mathrm{M}$ glucose was allowed to mutarotate at room temperature at least $3 \mathrm{~h}$ before use and stored at $4^{\circ} \mathrm{C}$. The stock solution of $0.1 \mathrm{M} \mathrm{H}_{2} \mathrm{O}_{2}$ was frequently assayed by titration with $0.1 \mathrm{~N} \mathrm{Ce}\left(\mathrm{SO}_{4}\right)_{2}$ using ferrous $o$-phenanthroline as indicator.

\section{Enzyme-collagen membranes}

(a) Preparation. The previously described acyl-azide procedure for activation of collagen followed by coupling of $\beta$-D-glucose oxidase was used [1,4]. The available carboxyl groups on collagen were first esterified by immersion of the crude membranes into a methanol/0.2 $\mathrm{M}$ hydrochloric acid solution for at least $72 \mathrm{~h}$ at room temperature; then these membranes were treated overnight with $1 \%$ aqueous hydrazine solution and for $3 \mathrm{~min}$ in a $0.5 \mathrm{M}$ sodium nitrite $/ 0.3 \mathrm{M}$ 


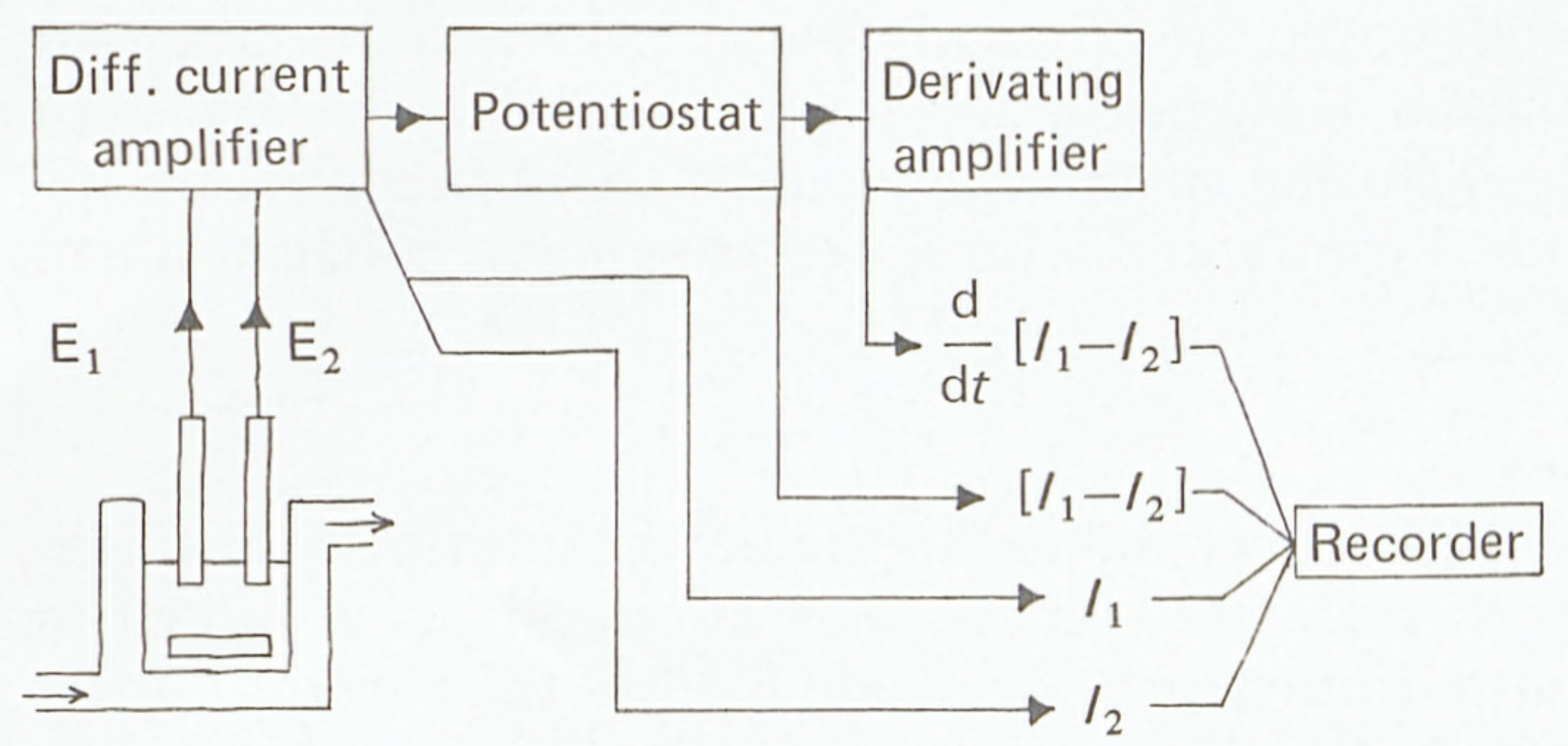

Fig. 1. Block diagram of electrodes and instruments. Potentiostat, constant voltage circuit.

hydrochloric acid mixture at $0-4^{\circ} \mathrm{C}$ prior to coupling. Thorough washings were performed at each step and at the end of the process. The enzyme coupling was obtained by $2-3 \mathrm{~h}$ immersion of activated membranes $(2.5 \times 1.5 \mathrm{~cm})$ in $1.5 \mathrm{ml}$ of $0.2 \mathrm{M}$ borate buffer or $0.05 \mathrm{M}$ glycine- $\mathrm{NaOH}$ buffer $\mathrm{pH} 9$, containing $2.5 \mathrm{mg}$ of $\beta$-D-glucose oxidase. After washing in $1 \mathrm{M} \mathrm{KCl}$ solution for 15-30 min, the enzymatic membranes were stored in $50 \mathrm{mM}$ acetate buffer $\mathrm{pH} 4.5$ at $0-4^{\circ} \mathrm{C}$.

(b) Measurement of activity. The enzymatic membranes were dipped into $9 \mathrm{ml} 0.2 \mathrm{M}$ acetate buffer ( $\mathrm{pH} 5.6$ ) containing $0.1 \mathrm{M}$ glucose at $30 \pm 0.1^{\circ} \mathrm{C}$ under constant magnetic stirring. $0.2 \mathrm{ml}$ of the reaction mixture were withdrawn every minute for $4 \mathrm{~min}$ and the hydrogen peroxide corresponding to the glucose oxidation, determined by adding $0.8 \mathrm{ml}$ of the peroxidase-ABTS reagent and measurement of the absorbance at $420 \mathrm{~nm}$ after $30 \mathrm{~min}$ [10].

\section{Instrumentation and glucose sensor}

The glucose sensor consisted of two electrodes; both electrodes contained a platinum disk, an $\mathrm{Ag} / \mathrm{AgCl}$ reference and a collagen membrane maintained in close contact by a screwed cap [4]. The electrodes $\mathrm{E}_{1}$ and $\mathrm{E}_{2}$ were filled with $0.2 \mathrm{M}$ acetate buffer, $0.1 \mathrm{M} \mathrm{KCl}, \mathrm{pH} 5.6$ and mounted with a $\beta$-D-glucose oxidase collagen membrane and a non-enzymatic one, respectively. Previously described electronics were adapted to the present study (Fig. 1).

Prior to an experiment, electrodes $E_{1}$ and $E_{2}$ were allowed to equilibrate in $20 \mathrm{ml} 50 \mathrm{mM}$ acetate buffer ( $\mathrm{pH} \mathrm{5.6)}$ ) for 15-30 min after stepping the potential of the working electrodes to $+650 \mathrm{mV}$ vs $\mathrm{Ag} / \mathrm{AgCl}$ references. Unless otherwise stated, the temperature was carefully controlled at $30.0 \pm 0.1^{\circ} \mathrm{C}$ using a Colora cryothermostat WK 5 DS.

\section{Results}

Glucose is oxidized in the presence of glucose oxidase according to the reaction:

$\beta$-D-Glucose $+\mathrm{O}_{2} \stackrel{\text { glucose oxidase }}{\longrightarrow} \mathrm{D}$-glucono- $\delta$-lactone $+\mathrm{H}_{2} \mathrm{O}_{2}$

When associating a glucose oxidase collagen membrane in close contact with the platinum anode of electrode $\mathrm{E}_{1}$, it is possible to detect amperometrically 
$\mathrm{H}_{2} \mathrm{O}_{2}$, a product of the reaction, and thus to study the kinetics and the modified behaviour of the immobilized enzyme under these conditions. In order to detect hydrogen peroxide diffusing in the bulk phase, the differential device includes a second electrode $\mathrm{E}_{2}$ mounted with a non-enzymatic collagen membrane as seen in Fig. 1.

\section{Glucose sensor responses}

When samples containing glucose are added to the buffer solution into which both electrodes are dipped, different signals may be recorded as shown in Fig. 1: $I_{1}$ is the current output of enzyme electrode $E_{1}, I_{2}$ is the current output of the non-enzymatic electrode $\mathrm{E}_{2}$.

As shown in Fig. 2, addition of glucose standards increases $\mathrm{I}_{1}$ which reaches a steady-state value after 3-5 $\mathrm{min}$; this is not an endpoint response since glucose is not completely converted within the reaction mixture, the very near vicinity of the membrane being only partially depleted. The inflexion of the $I_{1}$ vs time curve corresponding to the peak of its derivative, i.e. the dynamic response, is obtained after 30-90 s. When this device is used as a glucose sensor, $I_{2}$ compensates for electrochemical interferences such as ascorbate, uric acid and tyrosine: $\left(I_{1}-I_{2}\right)$ and its derivative $\mathrm{d}\left(I_{1}-I_{2}\right) / \mathrm{d} t$ allow an accurate determination of glucose in the range $1 \cdot 10^{-7}-2 \cdot 10^{-3} \mathrm{M}[4]$.

\section{Hydrogen peroxide fluxes: electrochemical determination}

Unlike many other enzymic membranes, enzyme molecules are not randomly distributed inside the collage matrix but form active layers, on both faces [9].
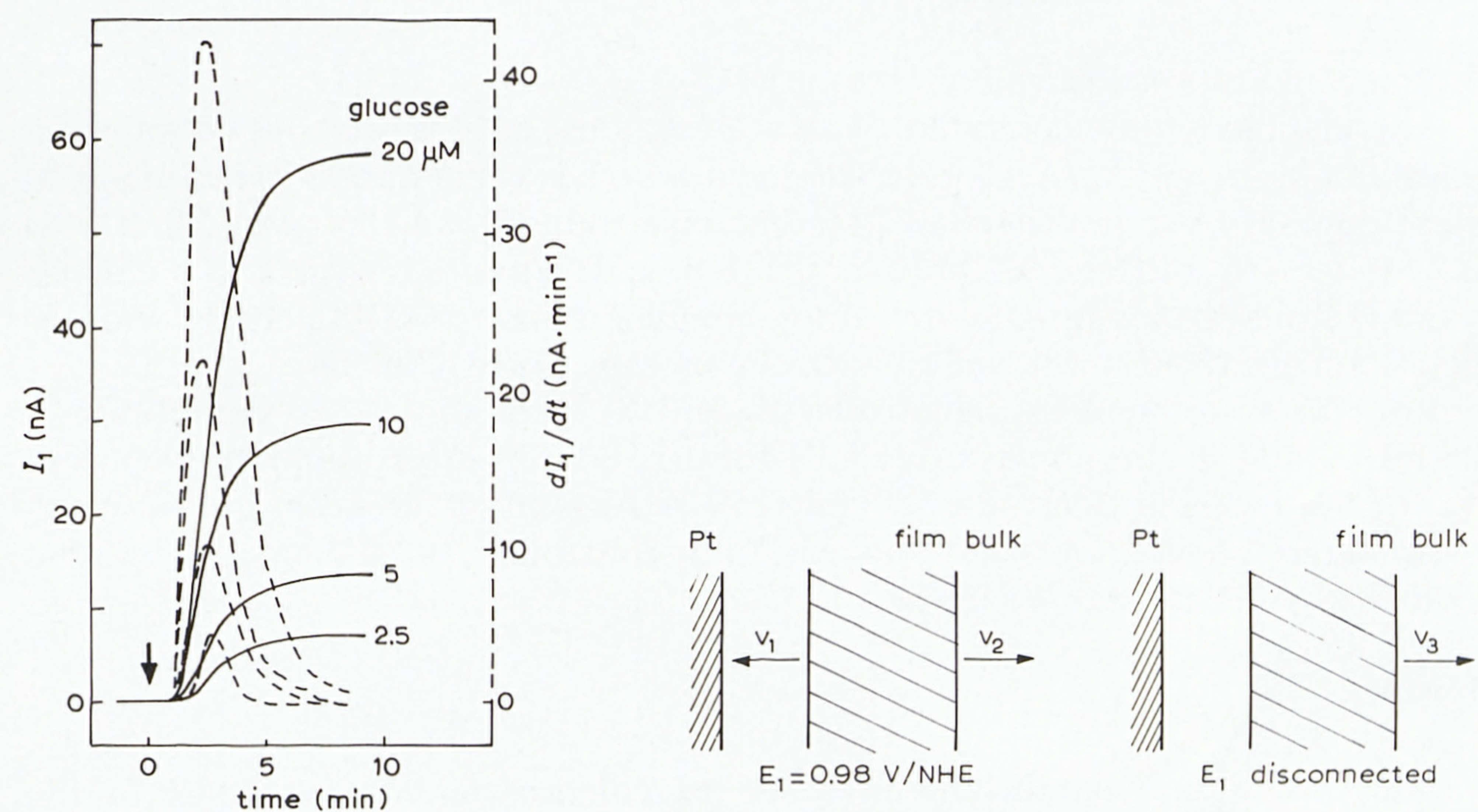

Fig. 2. Response of electrode $\mathrm{E}_{1}$ to different glucose pulses. The dy namic responses are indicated by the dashed lines.

Fig. 3. Scheme of hydrogen peroxide fluxes on electrode $E_{1}$ in contact with glucose solution. Platinum (Pt) disk anodically polarized (left) or disconnected (right). Film, glucose oxidase collagen membrane; bulk, bulk glucose solution. 
As the collagen membranes are permeable to small molecules, glucose may be oxidized either on the outer or on the inner face. In the first case, hydrogen peroxide crosses the membrane before reaching the platinum anode. In the latter, hydrogen peroxide is directly generated at the membrane-electrode interface. Two situations occur depending on the electrode $\mathrm{E}_{1}$ potential (Fig. $3)$ : when anodically polarized, part of hydrogen peroxide flux, $v_{1}$, is oxidized on platinum, the rest, $v_{2}$, diffusing towards the bulk solution; when $\mathrm{E}_{1}$ is disconnected, $v_{3}$ is the flux towards the bulk solution.

In a first set of experiments, where glucose concentration and temperature were kept constant, the three fluxes $v_{1}, v_{2}, v_{3}$ have been determined (Fig. 4). Initially both electrodes are dipped in the buffer solution and anodically polarized. An $\mathrm{H}_{2} \mathrm{O}_{2}$ pulse yields steady-state currents on $\mathrm{E}_{1}$ and $\mathrm{E}_{2}$ proportional to the $\mathrm{H}_{2} \mathrm{O}_{2}$ concentration:

$I_{1}=I_{2}=k\left[\mathrm{H}_{2} \mathrm{O}_{2}\right]$

Then glucose is added, $I_{1}$ increases and reaches a steady-state value proportional to $v_{1}$ expressed in mol per min

$v_{1}=\frac{60 I_{1}}{2 F}$

where $I_{1}$ is expressed in ampere, $F$ is the Faraday constant and 2 the number of electrons in the anodic oxidation of hydrogen peroxide

$\mathrm{H}_{2} \mathrm{O}_{2} \rightarrow \mathrm{O}_{2}+2 \mathrm{H}^{+}+2 e^{-}$

Simultaneously, $I_{2}$ increases showing that the hydrogen peroxide is building up

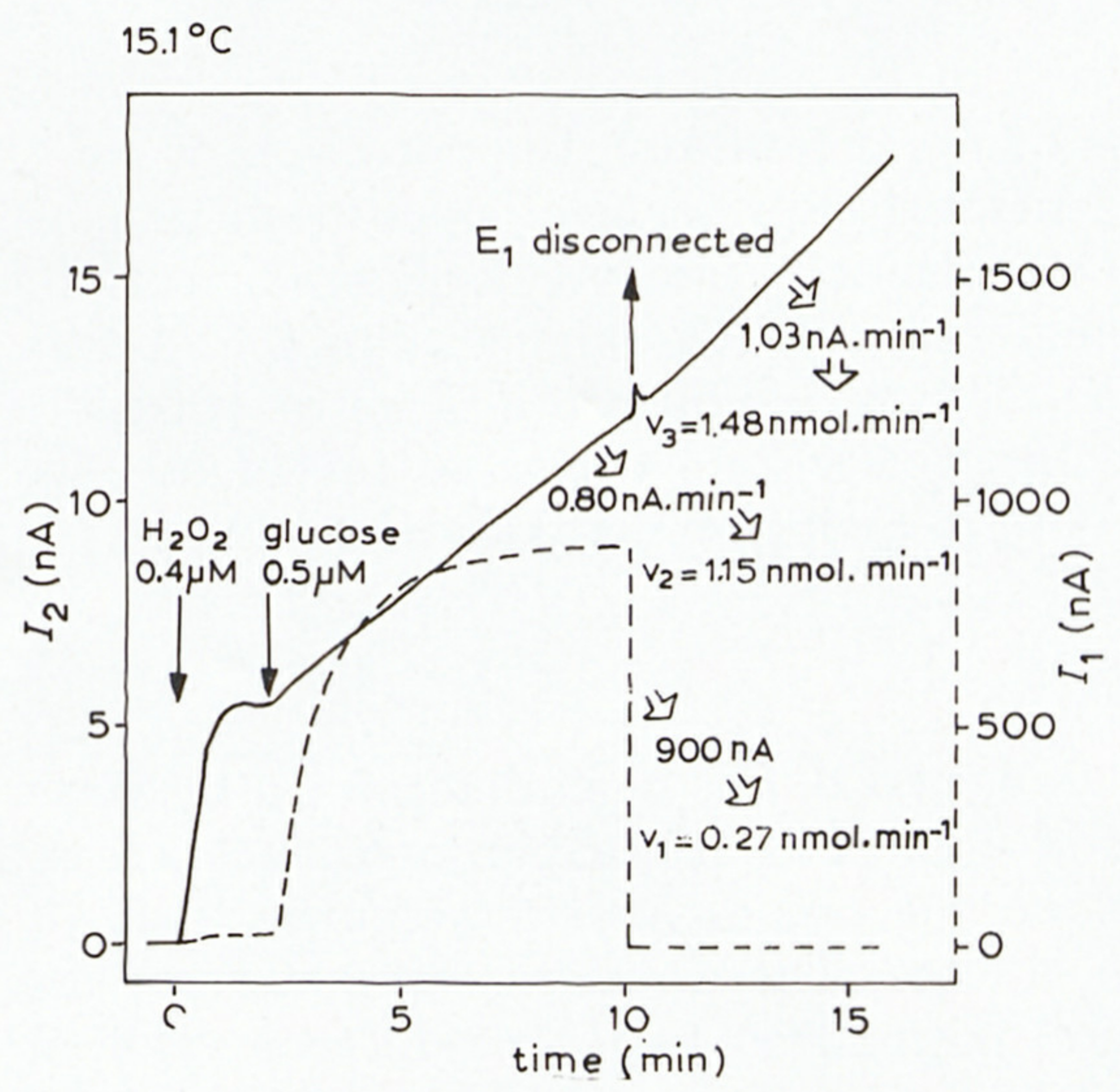

Fig. 4. Determination of hydrogen peroxide fluxes. Successive addition of $50 \mu 10.16$ mM hydrogen peroxide and $100 \mu \mathrm{l} 0.1 \mathrm{M}$ glucose solution into $20 \mathrm{ml}$ acetate buffer. Electrode $\mathrm{E}_{1}$, initially anodically polarized as electrode $\mathrm{E}_{2}$, is disconnected at the end of the experiment. Note the different ordinates used for each electrode. 
in the bulk solution. $v_{2}$ expressed in mol per min is given by

$v_{2}=\frac{\mathrm{d} I_{2}}{\mathrm{~d} t} \cdot V \cdot \frac{1}{k}$

where $\mathrm{d} I_{2} / \mathrm{d} t$ is in $\mathrm{A} / \mathrm{min}$ and $V$ is the volume of the reaction mixture. When $\mathrm{E}_{1}$ is disconnected, an increase of the slope of $I_{2}$ vs. time curve is observed, related to a faster building up of hydrogen peroxide in the soluton: $v_{3}$ is given by the same expression as $v_{2}$. Fig. 4 presents a typical experiment performed at $30^{\circ} \mathrm{C}$ in $0.5 \mathrm{mM}$ glucose. Values corresponding to the above described steps are indicated on the curves, $k$ being equal to $14 \mathrm{~mA} \cdot \mathrm{M}^{-1}$. Further experiments were performed with various glucose concentrations and temperatures. The overall reaction rate of immobilized glucode oxidase, which takes into account the intrinsic enzymatic activity and diffusional limitations in the enzyme microenvironment, has been determined on both electrodes under these conditions.

\section{Glucose concentration dependence}

When plotting the values of $v_{1}$ and $v_{2}$ obtained for different concentrations of glucose in the range $100 \mathrm{nM}-10 \mathrm{mM}$ (Fig. 5), a Michaelis-Menten like-curve is obtained but the double reciprocal plot $v^{-1}=f[\mathrm{~S}]^{-1}$ does not show a straight line suggesting the presence of diffusional limitations [11]. However the maximum values of $v_{1}$ and $v_{2}$ fluxes for high concentrations of glucose can be tentatively determined as shown in Fig. 5B. As the curves obtained under such conditions were not linear, $V_{1}$ and $V_{2}$ were estimated by the ordinate of the intercept of their tangents for the highest concentrations of glucose. Returning to the direct plot of Fig. $5 \mathrm{~A}$, the glucose concentrations $S_{0.5}$ leading to the half value of $V_{1}$ and $V_{2}$ were estimated to be 3.7 and $1.8 \mathrm{mM}$, respectively.

\section{Temperature dependence}

We have compared the influence of temperature on the detection of $\mathrm{H}_{2} \mathrm{O}_{2}$ either exogenous or enzymatically generated in presence of glucose and glucose oxidase. The addition of $\mathrm{H}_{2} \mathrm{O}_{2}$ into the reaction vessel yields an anodic current in the absence of glucose which reaches a steady-state value withing $0.5-1 \mathrm{~min}$. This response is proportional to $\mathrm{H}_{2} \mathrm{O}_{2}$ concentration in the range of $100 \mathrm{nM}-$ $10 \mathrm{mM}$. As previously mentionned for steady-state responses to glucose, we have expressed the steady-state response to hydrogen peroxide as a flux $v_{0}$ :

$v_{0}=60 \frac{I_{2}}{2 F}$

The temperature dependence of $v_{0}, v_{1}$ and $v_{2}$ has been determined between 15 and $40^{\circ} \mathrm{C}$. As seen on Fig. $6 \mathrm{~A}$ and $\mathrm{B}$ for a typical experiment, an increase of temperature has a smaller effect on the non-enzymatic response to $\mathrm{H}_{2} \mathrm{O}_{2}$ than on the enzymatic response to glucose. The direct representation of the $\mathrm{H}_{2} \mathrm{O}_{2}$ fluxes for a given temperature, normalized to their reference value at $15^{\circ} \mathrm{C}$, exhibits a quasi linear relation to temperature (Fig. 6A). The slopes for temperatures lower than $30^{\circ} \mathrm{C}$ are approximatively equal to $0.04,0.10$ and 0.09 per ${ }^{\circ} \mathrm{C}$ for $v_{0}, v_{1}$ and $v_{2}$ respectively. When plotting the experimental data of Fig. $6 \mathrm{~A}$ according to the Arrhenius representation, a non-linear pattern is 

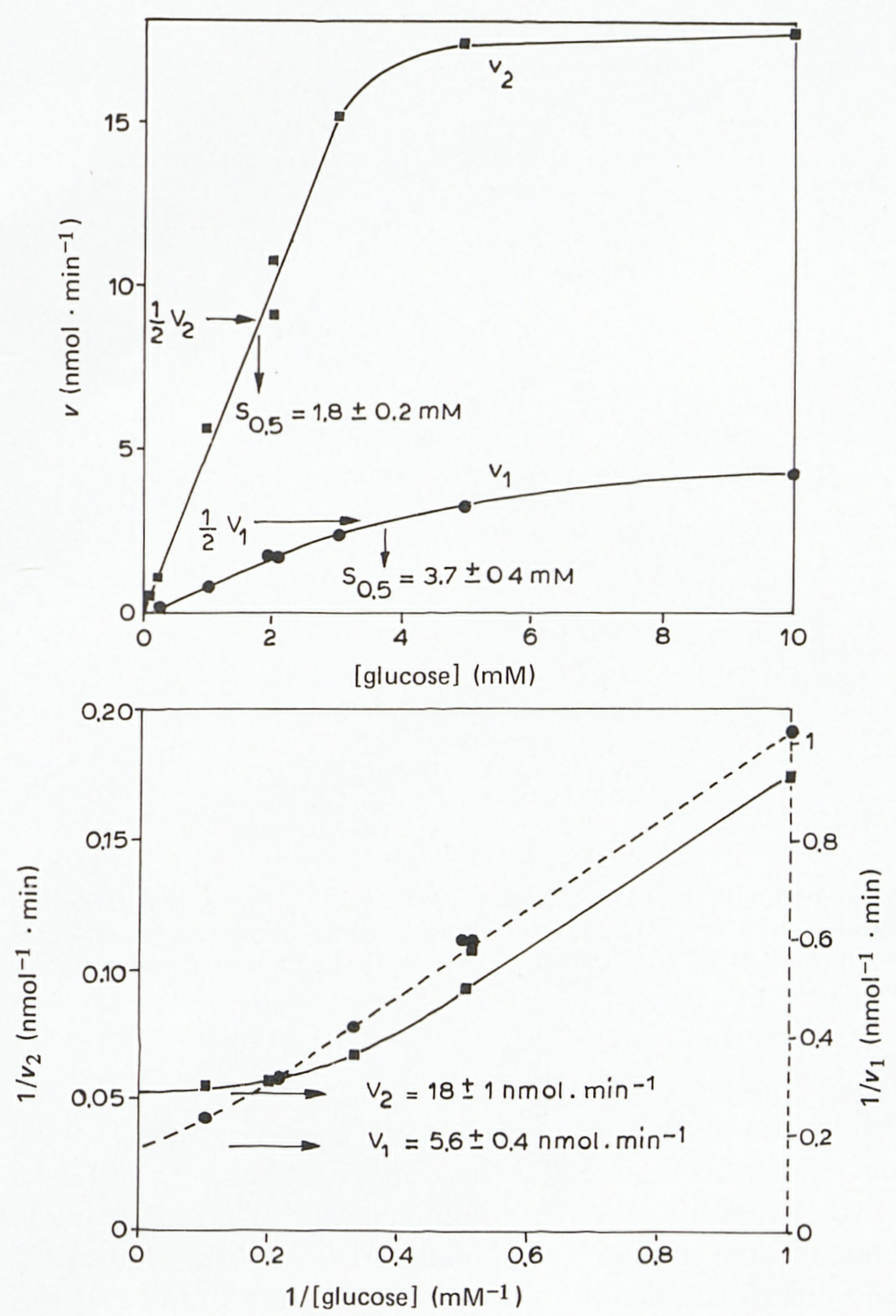

Fig. 5. Glucose concentration dependence of hydrogen peroxide fluxes $v_{1}(\bullet)$ and $v_{2}(\bullet)$. A (top), direct representation. B (bottom), Lineweaver-Burk plots. Note the different ordinates used for each electrode.

obtained (Fig. 6B). This is especially noticeable for $v_{1}$ and $v_{2}$. As previously mentioned for Lineweaver-Burk representations, such non-linear behaviour suggests diffusional limitations of enzymatic reactions. In this case, two activation energies were estimated around 15 and $40^{\circ} \mathrm{C}$. At these two temperatures, the values for $E_{\mathrm{a}}$ were 13 and $12 \mathrm{kcal} \cdot \mathrm{mol}^{-1}$ and 3.7 and $5.5 \mathrm{kcal} \cdot \mathrm{mol}^{-1}$ for $v_{1}$ and $v_{2}$, respectively. The comparison of these figures illustrates that mass transfer phenomena play a more prominent role in the overall reaction rate at higher temperatures.

\section{Hydrogen peroxide balance}

Comparison of $v_{1}, v_{2}$ and $v_{3}$. In order to study the balance of the different steady-state $\mathrm{H}_{2} \mathrm{O}_{2}$ fluxes occurring at the enzyme membrane level, on electrode 

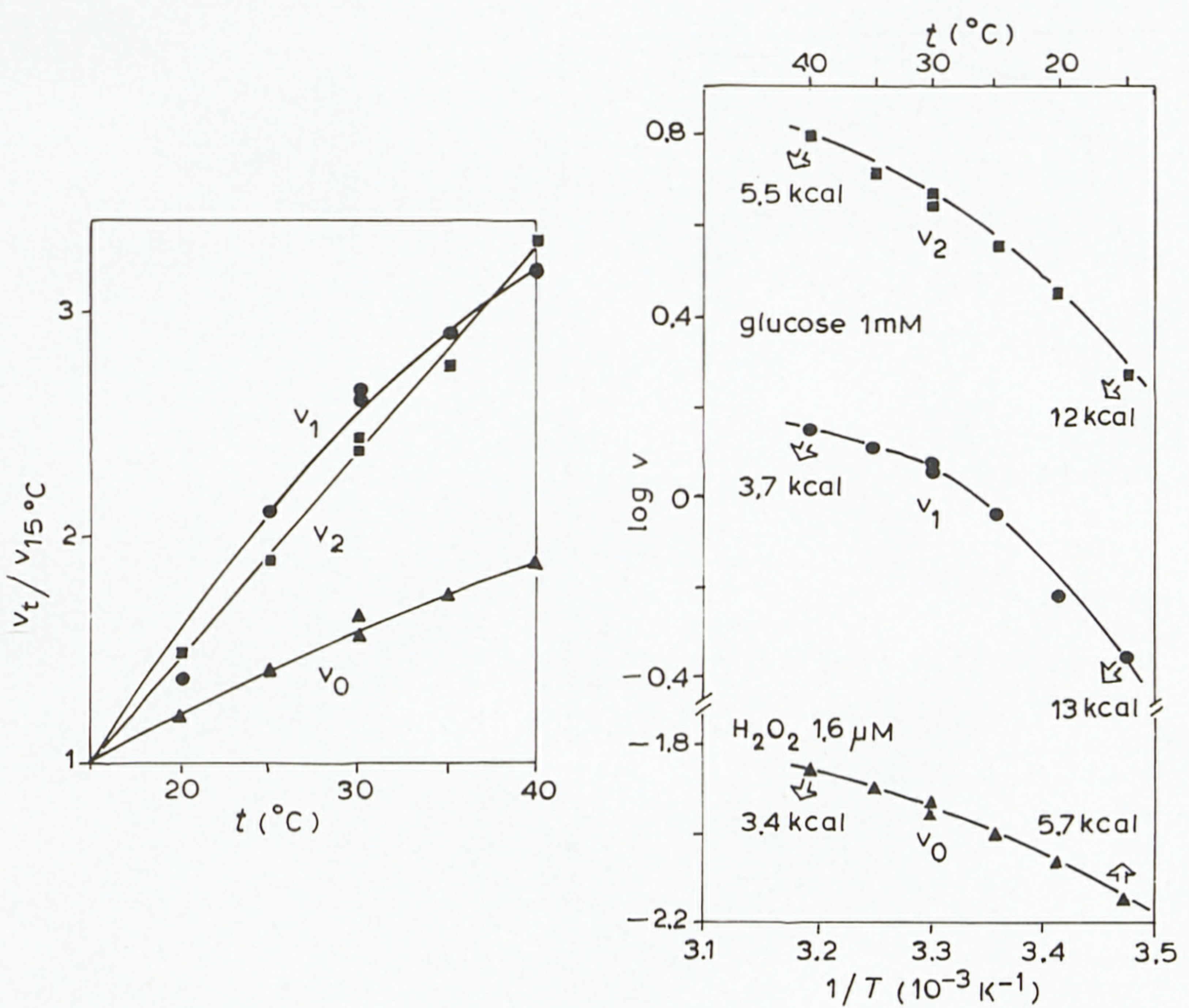

Fig. 6. Temperature dependence of hydrogen peroxide fluxes $v_{0}(\boldsymbol{\Delta}), v_{1}(\bullet)$ and $v_{2}(\boldsymbol{\bullet})$. Hydrogen peroxide and glucose solutions were $1.6 \mu \mathrm{M}$ and $1.0 \mathrm{mM}$, respectively. A (left), direct representation of fluxes normalized to their respective value at $15^{\circ} \mathrm{C}$. B (right), Arrhenius plots with corresponding activation energies values around 15 and $40^{\circ} \mathrm{C}$.

$\mathrm{E}_{1}$, experiments similar to those shown on Fig. 4 have been performed with temperatures ranging from 15 to $25^{\circ} \mathrm{C}$ and glucose concentrations from 0.1 to $1 \mathrm{mM}$ (Fig. 7). As the ratios $\left(v_{1}+v_{2}\right) / v_{3}$ were not significantly different from 1 , in these glucose concentration and temperature ranges, it is obvious that $\mathrm{H}_{2} \mathrm{O}_{2}$ does not accumulate at the interface between the enzymatic membrane and the platinum disk. Furthermore there is no evidence of any effect of polarization of the platinum disk on the activity of the membrane. On the other hand, as shown by $v_{1} / v_{3}$ ratios, $17 \%$ of hydrogen peroxide enzymatically generated is electrochemically oxidized on the platinum anode of $\mathrm{E}_{1}$. This percentage is independent of glucose concentration and temperature.

One side enzyme-bound collagen membrane. Glucose oxidase collagen membranes were specially prepared with enzyme bound to only one side. These membranes yield a larger response to glucose when the enzyme layer is pressed against the platinum disk: an increase of $160-260 \%$ of steady-state response $v_{1}$ was obtained showing that, although glucose has to diffuse through the membrane, the electrochemical detection of hydrogen peroxide is made easier when its enzymatic generation site is nearer to the electrode surface.

Collagen membranes freely stirred or mounted on electrode $E_{1}$. Maximum glucose oxidase activity was determined in $0.1 \mathrm{M}$ glucose solutions corresponding to saturating substrate concentration. This determination was performed with membranes either freely stirred or mounted on disconnected electrode $\mathrm{E}_{1}$, 

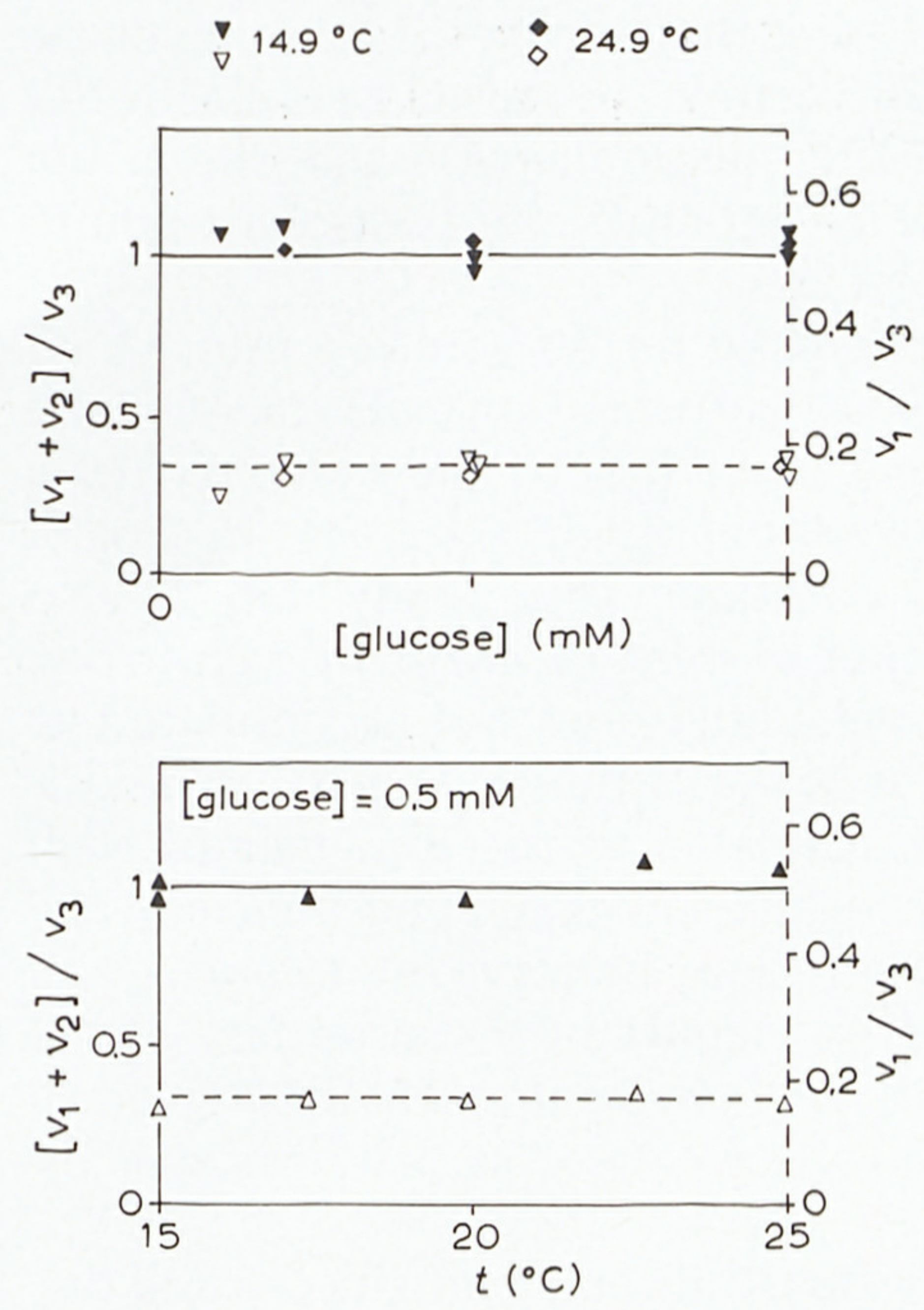

Fig. 7. Hydrogen peroxide balance. - $\left(v_{1}+v_{2}\right) / v_{3}$, and - - - - , $v_{1} / v_{3}$ ratios. A (top), glucose concentration dependence. $\mathrm{B}$ (bottom), temperature dependence.

using the non-enzymatic electrode $\mathrm{E}_{2}$. After calibration of the latter with hydrogen peroxide pulses, the rate of $I_{2}$ increase allowed the measurement of the corresponding values $V_{4}$ and $V_{3}$. The $V_{3} / V_{4}$ ratio was close to 0.26 . Enzymatic surfaces in contact with the bulk solution are $0.4 \mathrm{~cm}^{2}$, i.e. the aperture of the electrode cap when the membrane is mounted and $1.6 \mathrm{~cm}^{2}$ for both faces of the freely stirred membrane. Their ratio, 0.25 , is very close to the above mentioned one. This shows that the working area of the membrane mounted on the electrode is equivalent to its surface in contact with the bulk solution.

\section{Discussion}

The association of electrochemical sensors to enzymatic membranes, leading to the so-called enzyme electrodes [12] offers an opportunity for an experimental approach of heterogenous enzyme kinetics. Using a very sensitive electrochemical device we have been able to study new situations encountered when enzymatic membranes present only one side in contact with the stirred substrate solution.

Whereas previous electrochemical studies of such situations were generally performed with enzymes randomly distributed in an immobilized solution layer [4,13], in gels [15] or in cross-linked polymer matrixes [16,17], we have used reconstituted collagen membranes with surface-bound glucose oxidase on 
both sides [9]. Moreover, instead of monitoring the activity of the enzymatic membrane by a sole electrode placed in its vicinity; we used two electrodes simultaneously, one in close contact with the membrane $\left(E_{1}\right)$ and one in the bulk solution $\left(\mathrm{E}_{2}\right)$. This device enabled us to monitor the membrane-bound glucose oxidase activity from two different points.

When a pulse of glucose is added to the stirred buffer solution into which both electrodes are dipped, hydrogen peroxide is formed on both faces of the membrane. The linear increase of the output current $I_{2}$ of the non-enzymatic electrode $\mathrm{E}_{2}$ demonstrates that, in steady-state conditions, the hydrogen peroxide flux towards to bulk solution is constant. This steady-state is also visualized by the constant level of the output current of enzymatic electrode $\mathrm{E}_{1}$. The hydrogen peroxide enzymatically generated does not accumulate but diffuses towards the platinum disk of $\mathrm{E}_{1}$ or towards the bulk phase. The difference between $E_{1}$ and $E_{2}$ output signals, is related to the influence of each electrodes on its environment: whereas $\mathrm{E}_{2}$ presents a negligible influence on the hydrogen peroxide building-up in the bulk solution, $\mathrm{E}_{1}$ plays the role of a well attracting hydrogen peroxide in the immediate vicinity of the inner face of the membrane. Thus, when $\mathrm{E}_{1}$ is disconnected, this hydrogen peroxide depletion stops and its building up in the bulk phase is accelerated, as demonstrated by the increase of $\mathrm{d} I_{2} / \mathrm{d} t$.

The apparent equilibrium constant of the reaction between glucose and dissolved oxygen, as determined by the respective oxidoreduction potentials of the oxygen/hydrogen peroxide and gluconate/glucose systems, reaches 9.3 . $10^{22}$ at $\mathrm{pH}$ 5.7. Thus, the occurrence of a hydrogen peroxide well in the vicinity of the enzymatic membrane has no influence on its activity. This was experimentally demonstrated by the balance of hydrogen peroxide generation when electrode $\mathrm{E}_{1}$ is polarized or disconnected.

The simultaneous monitoring of hydrogen peroxide fluxes $v_{1}$ and $v_{2}$ towards $E_{1}$ and $E_{2}$ respectively, offers interesting possibilities for the determination of the rate limiting steps in the activity of the enzymatic membrane. The importance of diffusional limitations seems to be higher for $v_{1}$ as shown by its larger $S_{0.5}$ value (3.7 instead of $1.8 \mathrm{mM}$ ). We propose the following interpretation of these results. Glucose, if not completely depleted at the outer face level, has to diffuse through the membrane before being oxidized at the inner face level. Experiments done with glucose oxidase bound to only one side of the collagen membrane have indeed demonstrated that hydrogen peroxide molecules generated on the inner face of the membrane are more easily detected by the $\mathrm{E}_{1}$ platinum anode than those produced on the outer face. However, as the outer face of the enzymatic collagen membrane is better exposed to glucose than the inner one, hydrogen peroxide is probably mainly generated on the outer face and has to diffuse through the membrane before reaching the $\mathrm{E}_{1}$ platinum anode. Thus, whatever the contributions of both faces of the membrane in the production of the hydrogen peroxide flux $v_{1}$ detected on $\mathrm{E}_{1}$, the necessity for both glucose and hydrogen peroxide to cross the membrane involves the occurrence of diffusion limitations more apparent on $v_{1}$ than on $v_{2}$.

Furthermore, we were able to define a working area by comparing the activity of an enzyme membrane either when freely stirred or when mounted 
on $E_{1}$ : the working area was equivalent to the membrane external surface in contact with the solution but the contribution of each face of the membrane has not yet been elucidated.

Finally, we think that the use of very sensitive electrochemical sensors placed both in the immediate vicinity of the membrane and in the bulk phase. offers a simple and promising experimental approach of heterogenous enzyme kinetics and a better understanding of their rate limiting steps.

\section{References}

1 Coulet, P.R., Julliard, J.H. and Gautheron, D.C. (1974) Biotechnol. Bioeng. 16, 1055-1068

2 Coulet, P.R., Godinot, C. and Gautheron, D.C. (1975) Biochim. Biophys. Acta 391, 272-281

3 Arrio-Dupont, M. and Coulet, P.R. (1979) Biochem. Biophys. Res. Commun. 89, 345-352

4 Thévenot, D.R., Sternberg, R., Coulet, P.R., Laurent, J. and Gautheron, D.C. (1979) Anal. Chem. 51, 96-100

5 Katchalski, E., Silman, I. and Goldman, R. (1971) Adv. Enzymol. 34, 445-536

6 Engasser, J.M. and Horvath, C. (1976) in Applied Biochemistry and Bioengineering (Wingard, L.B. Jr., Katchalski, E. and Goldstein, L., Eds.), Vol. 1, pp. 127-220, Academic Press, New York, NY

7 Engasser, J.M., Coulet, P.R. and Gautheron, D.C. (19'77) J. Biol. Chem. 252, 7919-7922.

8 Paul, F., Coulet, P.R., Gautheron, D.C. and Engasser, J.M. (1978) Biotechnol. Bioeng. 20, 1785-1796

9 Coulet, P.R. and Gautheron, D.C. (1976) in Analysis and Control of Immobilized Enzyme Systems (Thomas, D. and Kernevez, J.P., Eds.), pp. 165-177, North-Holland, Amsterdam

10 Bergmeyer, H.U. (1974) in Methods of enzymatic analysis (Bergmeyer, H.U., Ed.), Vol. 3, p. 1212, Verlag Chemie and Academic Press, New York, NY

11 Horvath, C. and Engasser, J.M. (1974) Biotechnol. Bioeng. 16, 909-923

12 Guilbault, G.G. (1975) in Immobilized Enzymes, Antigens, Antibodies and Peptides (Weetall, H.H., Ed.), pp. 293-417, Marcel Dekker, New York, NY

13 Racine, P. and Mindt, W. (1971) Experientia Suppl. 18, 525-534

14 Durliat, H., Comtat, M., Mahenc, J. and Baudras A. (1976) Anal. Chim. Acta 85, 31-40

15 Blaedel, W.J., Kissel, T.R. and Boguslaski, R.C. (1972) Anal. Chem., 44, 2030-2037

16 Tran-Minh, C. and Broun, G. (1975) Anal. Chem. 47, 1359-1364

17 Shu, F.R. and Wilson, G.S. (1976) Anal. Chem. 48, 1679-1686 